\title{
THE GOOD TEACHER ATTRIBUTES - A CROSS SECTIONAL STUDY ON TEACHING EVALUATION AT REHMAN MEDICAL COLLEGE, PESHAWAR.
}

1. MBBS, MPH

Assistant Professor

Department of Community Medicine

Rehman Medical College,

Peshawar.

2. MBBS

Medical Officer

Health Department KPK.

Correspondence Address:

Dr. Ali Raza

Department of Community Medicine

Rehman Medical College, Peshawar.

Opposite Rehman Medical Institute

Hayatabad Phase V.

doctor.raza@hotmail.com

Article received on:

25/02/2019

Accepted for publication:

$15 / 05 / 2019$

Received after proof reading:

$22 / 05 / 2019$

\section{Ali Raza', Hajira Zainab²}

ABSTRACT... The role of teacher is crucial to a college's/ university success. Teaching evaluation when done properly enhances teacher's professional practice as well as aids in professional development. There is a clearer link between student learning standards and teacher preparation standards, as teaching evaluation is relevant to every segment of the educational system. This is a controversial area involving technical, psychological, political, ethical and educational complexities. The purpose of this study is to present qualities of a good teacher as are evaluated by Higher Education Commission (HEC) teaching evaluation survey. Study Design: Cross sectional study. Setting: Rehman Medical College, Peshawar. Period: April to October 2017. Materials and Methods: The survey was conducted by quality enhancement cell. The senior faculty i.e assistant professor and above of respective subjects were evaluated by the students. The survey was done from year 1 to year 4 MBBS. The total number of responses for all subjects were 2189. Results: Year wise and subject wise analysis was done using ANOVA and chi-square tests. The difference between the students' perception year and subject wise was depending on total faculty effectiveness score. However, individual item analysis also showed certain differences which were more due to the teachers' influence on the students. The disagreement level for 1st and 2nd year MBBS as compared to other professional years was consistently high which desires further probation. Conclusion: Although teaching evaluation is a very difficult area and involves controversy. Individual to individual feedback can improve the situation. Regular professional development workshops will develop teachers professionally.

Key words: $\quad$ Attributes, Evaluation, Good Teaching, Teaching Evaluation, Role Model.

Article Citation: Raza A, Zainab H. The good teacher attributes - a cross sectional study on teaching evaluation at Rehman Medical College, Peshawar. Professional Med J 2019; 26(6):881-888. DOI: 10.29309/TPMJ/2019.26.05.3445

\section{INTRODUCTION}

Evaluation is part of education and a way to improve purposes, plans and teaching methods ${ }^{1}$ by determining its merit or worth, as mentioned by Stufflebeam. Medical students are selfdirected learners but it is the duty of the teacher to facilitate the learning process with effective teaching strategies, clarifying and organizing the purpose of learning and its resources, creating positive climate for learning so that students know how to learn and utilize their knowledge and time appropriately. ${ }^{2,3}$

According to Harden and Crosby, Teaching is a demanding and complex task (4) and because of this reason teaching faculty, supporting staff and class room facilities are key satisfaction components. ${ }^{5,6}$
Quality and medical education departments are mandated to measure teaching effectiveness based on students' perception using structured questionnaires and it is a common practice. ${ }^{7}$ Although these ratings that can be used both as formative as well as summative; they might have an element of bias. These ratings are effected by initial interest of students, teacher's reputation and his/her enthusiasm and their "Entertainment Value". ${ }^{8}$ Validity of these questionnaires used, age maturity of students have also been questioned by various researchers and teachers who are being evaluated. ${ }^{9}$ Thus, students' fill these questionnaires based on their past experiences and fractional knowledge of the evaluation process. $^{8}$

Teaching evaluation is a controversial area 
involving technical, psychological, political, ethical and educational complexities. It is an established fact that students have to adapt to different styles of each instructor, ${ }^{10}$ and this may compromise academic productivity if wide deviations exist.

Who is a good teacher then? Literature lacks allencompassing definition of a good teacher. It is an uphill task to delineate the minimum attributes of a good and effective teacher. A good teacher is someone who aligns behavior, competencies, beliefs and professional identity in his students' personality. ${ }^{11}$

Both quantitative and qualitative work has been published regarding the teaching effectiveness and quality of teaching. The national task force in Netherlands examined the roles of teachers. The framework extricated six ${ }^{6}$ domains of teaching; development, organization, execution, coaching, assessment and evaluation. These domains were applicable to 3 levels of operational work area for a teacher. Micro, which involved direct teaching and involvement with small group format. Meso, which included senior faculty; involved in curriculum making and its impact on students. Macro, which included leadership and policy making positions. ${ }^{12}$ Harden and Crosby mentioned 12 roles of good teachers grouped in 6 areas. These roles included teacher as information provider, a role model on job, facilitator and a mentor, student assessor and curriculum evaluator, curriculum and course planner and his role as resource material creator and study guide producer. $^{4}$

Based on these two broad frameworks, attributes of a good teacher are critical and reflective thinker, one who updates his knowledge and skills, problem solver, self-directed lifelong learner, good communication skills, honest, respectful of values and perspective of others, easily accessible, non-threatening, intrinsically motivated, good manager, role model and leader, open to new ideas, productive worker, time manager, committed, creative, researcher and evidence based practitioner, feedback provider, compassionate and culturally competent. ${ }^{2}$
Dividing the attributes into cognitive and noncognitive characteristics, Sutkin et al identified almost 500 descriptors of good teachers. ${ }^{13}$ Development of an evaluation instrument, that encompasses all these descriptors mentioned above is difficult, hence we used evaluation forms based on Jacobson six criteria. The six criteria includes; professional competence, teaching and evaluation practices, personal characteristics, interpersonal relationship and availability to the students. ${ }^{9}$

Majority of medical faculty learn teaching through observation of their teachers and mentors. This analogy accentuates the need to be aware of the qualities of an effective teacher in order to bring improvement in one's teaching practices fit for the profession. ${ }^{14}$

The objective of this study was to identify teaching attributes most valued by the undergraduate students of Rehman Medical College, Peshawar from $1^{\text {st }}$ year to $4^{\text {th }}$ year MBBS using teaching evaluation questionnaire of Higher Education Commission (HEC) - Pakistan. Secondly, to find year and subject wise correlation with total faculty effectiveness score.

\section{METHODS}

This cross sectional study was conducted at Rehman Medical College, Peshawar from April to October 2017 as part of the quality assurance activities undertaken by the Quality Enhancement Cell (QEC). The cell was established in 2012 and recognized by quality assurance department of Khyber Medical University.

QEC - Rehman Medical College perform evaluations annually at the end of academic sessions using prescribed survey forms of Higher Education Commission, Pakistan. The data is then used to generate an assessment report, which is verified by external reviewers.

Students from $1^{\text {st }}$ year to $4^{\text {th }}$ year MBBS were given the survey form. The final (5th) year is devoted to hospital rotations and very limited class room teaching is done in final year. Hence, we excluded final year teaching faculty in this study. 
Teaching faculty from $1^{\text {st }}$ year to $4^{\text {th }}$ year MBBS was included in analysis. Senior teachers not less than the rank of assistant professors were selected for teaching evaluation. The rationale for selecting senior teachers is, first of all they are the permanent faculty members of a department with post graduate qualification in relevant subject. They are actively involved in mentoring, facilitation and teaching of small group and large group classes of students. Another reason can be that students hold high ideals about senior faculty, as they are also involved in management and administration of their departments.

Data were collected using close ended questionnaire containing 13 questions to be marked on a 5 point Likert Scale. The questions pertained to students' perception about teaching of individual teacher.

\section{STATISTICAL ANALYSIS}

The data were entered and analyzed using Statistical Package for Social Sciences (SPSS) version 16. In our analysis, the 5 point satisfaction scale responses were reduced to 3 . Hence, Strongly Agree and Agree had a combined score of 3 . Uncertain responses were given 2 and Disagree and Strongly Disagree responses were given a score of 1 .

Descriptive statistics were calculated. Normality check was performed to check if the data were normally distributed. Correlation analysis was done to compare professional years and subjects with total faculty effectiveness score. P-value was calculated and a value of 0.05 was taken as significant.

\section{RESULTS}

A total of 23 faculty members from 1 st year to 4 th year MBBS with 10 departments were evaluated by 262 students comprising a total of 2189 survey forms. Missing and incomplete forms were excluded from analysis from the total number of forms received for each year.

Table-I shows year wise details; number of teachers and number of students who participated in the survey. The subjects and faculty members in 1st and 2nd year MBBS remain same and only student population changes. Results from the survey forms were mentioned in 4 major thematic areas: content, learning environment, teaching methods, and teachers' personal attributes. The Total Faculty Effectiveness Score for the Likert Scale Items was 39.

Table-Il shows year wise mean of the teaching evaluation attributes based on 4 thematic areas. The normality tests Kolmogorov-Smironov and Shapiro-Wilk were significant for the attributes hence, the data was not normally distributed. We analyzed data using Spearman's Rho - a non-parametric measure to look for correlational strength between total faculty effectiveness score and other attributes in the survey form. Year and subject were controlled in the analysis process.

Table-III showed top three attributes which were highly correlated with faculty effectiveness score were effective communication skills followed by teachers demonstration of knowledge and his ability to maintain conducive learning environment with P-value $<0.01$. Attributes with relatively weak correlation included faculty's personal attribute of punctuality and time management (underlined and italicized). Most of the attributes scored quite similar i.e there was not much deviation although less than the attributes in bold. These attributes show potential areas of improvement.

The students of $1^{\text {st }}$ and $2^{\text {nd }}$ year MBBS were found to be more critical in evaluation as compared to senior students which can be explained by more adjustment of senior students in the college's environment and more familiarity with the college's system. Teachers' role of spoon feeding rather than encouraging self-directed learning can also be reason of this critical appraisal. Figure-1 shows the year wise agreement variation.

Table-V shows department wise mean total faculty effectiveness score along with means for particular years. Similarly, Figure-2 shows subject wise mean score variation. The Spearmans' Rho for total score and subject is significant for $1^{\text {st }}$ year and for two subjects in $2^{\text {nd }}$ year MBBS. This can be interpreted this way that faculty effectiveness 
for these years cannot be explained by factors presented in this form. There may be other factors which would be influencing the teaching practices in these years particularly $1^{\text {st }}$ year MBBS.

\begin{tabular}{|l|l|l|l|c|c|}
\hline $\begin{array}{c}\text { MBBS } \\
\text { Year }\end{array}$ & \multicolumn{3}{|c|}{ Subjects } & $\begin{array}{c}\text { Total Teachers } \\
\mathbf{N = 3 3}\end{array}$ & $\begin{array}{c}\text { Total Students } \\
\mathbf{N}=\mathbf{2 6 2}(\%)\end{array}$ \\
\hline $1^{\text {st }}$ Year & Anatomy & Physiology & Biochemistry & 07 & $69(26.30)$ \\
\hline $2^{\text {nd }}$ Year & Anatomy & Physiology & Biochemistry & 07 & $84(32.10)$ \\
\hline $3^{\text {rd }}$ Year & Pharmacology & Pathology & Forensic Medicine & 07 & $38(14.50)$ \\
\hline $4^{\text {th }}$ Year & Eye & Pathology & $\begin{array}{l}\text { Community Medicine } \\
\text { Table-I. Year wise detail of subjects. }\end{array}$ & 12 & $71(27.10)$ \\
\hline
\end{tabular}

\begin{tabular}{|c|c|c|c|c|}
\hline Instructor Evaluation Items & $\begin{array}{c}1^{\text {st }} \text { yr. } \\
N=471 \\
\text { Mean }\end{array}$ & $\begin{array}{l}2^{\text {nd }} \text { yr. } \\
N^{\prime}=588 \\
\text { Mean }\end{array}$ & $\begin{array}{c}3^{\text {rd }} \text { yr. } \\
N=271 \\
\text { Mean }\end{array}$ & $\begin{array}{c}4^{\text {th }} \text { yr. } \\
N=846 \\
\text { Mean }\end{array}$ \\
\hline \multicolumn{5}{|l|}{ Content } \\
\hline Demonstration of Knowledge & 2.64 & 2.65 & 2.89 & 2.80 \\
\hline Additional material apart from textbook & 2.42 & 2.25 & 2.72 & 2.58 \\
\hline $\begin{array}{l}\text { Citations regarding current situation with reference to Pakistani } \\
\text { context }\end{array}$ & 2.23 & 2.13 & 2.59 & 2.56 \\
\hline \multicolumn{5}{|l|}{ Teaching Methods } \\
\hline Preparation for each class & 2.63 & 2.71 & 2.91 & 2.78 \\
\hline Completed the whole course & 2.68 & 2.75 & 2.83 & 2.64 \\
\hline $\begin{array}{l}\text { Feedback and returning of graded scripts in reasonable amount } \\
\text { of time }\end{array}$ & 2.42 & 2.44 & 2.70 & 2.50 \\
\hline \multicolumn{5}{|l|}{ Learning Environment } \\
\hline Shows respect towards students & 2.48 & 2.31 & 2.74 & 2.66 \\
\hline Maintains an environment that is conducive to learning & 2.49 & 2.45 & 2.73 & 2.65 \\
\hline \multicolumn{5}{|l|}{ Teachers' Personal Attributes } \\
\hline Communicates the subject matter effectively & 2.51 & 2.45 & 2.74 & 2.70 \\
\hline Arrives on time & 2.71 & 2.77 & 2.90 & 2.84 \\
\hline Leaves on time & 2.62 & 2.67 & 2.81 & 2.83 \\
\hline Fair in examination & 2.61 & 2.41 & 2.77 & 2.78 \\
\hline $\begin{array}{l}\text { Available during the specified hours and for after class } \\
\text { consultation }\end{array}$ & 2.57 & 2.54 & 2.81 & 2.74 \\
\hline Total Faculty Effectiveness Score & 33.08 & 32.51 & 36.14 & 35.09 \\
\hline
\end{tabular}

Table-II. Year wise attribute mean scores

\section{Instructor Evaluation Items}

\section{Content}

Demonstration of Knowledge

Additional material apart from textbook

Citations regarding current situation with reference to Pakistani context

Teaching Methods

Preparation for each class

Completed the whole course

Feedback and returning of graded scripts in reasonable amount of time

Learning Environment

Shows respect towards students

Maintains an environment that is conducive to learning

Teachers' Personal Attributes

Communicates the subject matter effectively

Arrives on time

Leaves on time

Fair in examination

Available during the specified hours and for after class consultation
Correlation

.740

.688

.611

.730

.692

.633

.713

.740

.768

.599

.602

.673

.680
P-Value (2 - Tailed Significance)

$P<0.01$

$P<0.01$

$P<0.01$

$P<0.01$

$P<0.01$

$P<0.01$

$P<0.01$

$P<0.01$

$P<0.01$

$P<0.01$

$P<0.01$

$P<0.01$

$P<0.01$

$P<0.01$

$P<0.01$

$P<0.01$

Table-III. Correlation analysis of total faculty effectiveness score and other attributes. 


\begin{tabular}{|c|c|c|c|c|c|c|c|c|}
\hline \multirow{2}{*}{ Instructor Evaluation Items } & \multicolumn{2}{|c|}{$1^{\text {st }} \mathrm{yr}}$. & \multicolumn{2}{|c|}{$2^{\text {nd }} \mathrm{yr}}$. & \multicolumn{2}{|c|}{$3^{\mathrm{rd}} \mathrm{yr}}$. & \multicolumn{2}{|r|}{$4^{\text {th }} \mathrm{yr}}$. \\
\hline & $\underset{\%}{\text { Agree }}$ & $\begin{array}{c}\text { Disagree } \\
\%\end{array}$ & $\underset{\%}{\text { Agree }}$ & $\begin{array}{c}\text { Disagree } \\
\%\end{array}$ & $\begin{array}{l}\text { Agree } \\
\%\end{array}$ & $\begin{array}{c}\text { Disagree } \\
\%\end{array}$ & $\begin{array}{l}\text { Agree } \\
\%\end{array}$ & Disagree \% \\
\hline \multicolumn{9}{|l|}{ Content } \\
\hline $\begin{array}{l}\text { Demonstration of } \\
\text { Knowledge }\end{array}$ & 76.9 & 12.9 & 76.5 & 11.9 & 91.9 & 3.0 & 84.6 & 5.0 \\
\hline $\begin{array}{l}\text { Additional material apart } \\
\text { from textbook }\end{array}$ & 63.1 & 21.2 & 52.4 & 27 & 76.3 & 4.4 & 70.3 & 12.8 \\
\hline $\begin{array}{l}\text { Citations regarding current } \\
\text { situation with reference to } \\
\text { Pakistani context }\end{array}$ & 52.7 & 29.6 & 42.3 & 29.3 & 69.5 & 10.8 & 68.3 & 12.3 \\
\hline \multicolumn{9}{|l|}{ Teaching Methods } \\
\hline Preparation for each class & 78.6 & 15.3 & 80 & 9.4 & 93.7 & 2.6 & 85.6 & 7.2 \\
\hline Completed the whole course & 81.3 & 13.4 & 82.1 & 7.5 & 87 & 3.7 & 75.9 & 12.3 \\
\hline $\begin{array}{l}\text { Feedback and returning of } \\
\text { graded scripts in reasonable } \\
\text { amount of time }\end{array}$ & 61.3 & 19.8 & 60.5 & 16.2 & 73.6 & 3.7 & 63.2 & 12.8 \\
\hline \multicolumn{9}{|l|}{ Learning Environment } \\
\hline $\begin{array}{l}\text { Shows respect towards } \\
\text { students }\end{array}$ & 67.1 & 19.3 & 58.3 & 27.6 & 81.8 & 7.4 & 77.6 & 11.5 \\
\hline $\begin{array}{l}\text { Maintains an environment } \\
\text { that is conducive to learning }\end{array}$ & 69.1 & 20.2 & 66.2 & 21.5 & 79.9 & 6.7 & 76.1 & 10.7 \\
\hline \multicolumn{9}{|l|}{$\begin{array}{l}\text { Teachers' Personal } \\
\text { Attributes }\end{array}$} \\
\hline $\begin{array}{l}\text { Communicates the subject } \\
\text { matter effectively }\end{array}$ & 69.3 & 18.1 & 66 & 21.1 & 83.3 & 8.9 & 80 & 10.5 \\
\hline Arrives on time & 82.1 & 11 & 84.8 & 8.2 & 91.8 & 2.2 & 89.2 & 5.7 \\
\hline Leaves on time & 74.9 & 13.4 & 78.9 & 11.6 & 87.4 & 6.7 & 89.5 & 6.1 \\
\hline Fair in examination & 77.7 & 16.5 & 64.5 & 23.2 & 83.6 & 6.3 & 84.5 & 6.1 \\
\hline $\begin{array}{l}\text { Available during the } \\
\text { specified hours and for after } \\
\text { class consultation }\end{array}$ & 70.1 & 12.8 & 68.3 & 14.6 & 86.2 & 5.2 & 80.9 & 6.8 \\
\hline
\end{tabular}

Table-IV. Year wise attributes agreement and disagreement percentage analysis

\begin{tabular}{|c|c|c|c|c|c|}
\hline S. No. & Year & $\begin{array}{l}\text { Mean Faculty Evaluation } \\
\text { Score for the Year }\end{array}$ & $\begin{array}{c}\text { MBBS } \\
\text { Departments }\end{array}$ & $\begin{array}{c}\text { Faculty Effectiveness } \\
\text { Score for the Dept. } \\
\text { Mean + S.D }\end{array}$ & $P$ - Value \\
\hline 1 & \multirow{3}{*}{$1^{\text {st }}$ year } & \multirow{3}{*}{33.08} & Anatomy & $33.85+6.32$ & 0.001 \\
\hline 2 & & & Physiology & $34.10+6.36$ & $P<0.001$ \\
\hline 3 & & & Biochemistry & $31.89+7.72$ & $P<0.001$ \\
\hline 4 & \multirow{3}{*}{$2^{\text {nd }}$ year } & \multirow{3}{*}{32.51} & Anatomy & $33.04+5.64$ & $P<0.001$ \\
\hline 5 & & & Physiology & $34.15+4.81$ & 0.003 \\
\hline 6 & & & Biochemistry & $31.07+7.05$ & 0.890 \\
\hline 7 & \multirow{3}{*}{$3^{\text {rd }}$ year } & \multirow{3}{*}{36.14} & Pharmacology & $37.49+2.94$ & 0.861 \\
\hline 8 & & & Pathology & $36.68+2.88$ & 0.122 \\
\hline 9 & & & Forensic Medicine & $34.03+6.29$ & 0.015 \\
\hline 10 & \multirow{4}{*}{$4^{\text {th }}$ year } & \multirow{4}{*}{35.09} & Special Pathology & $36.55+3.37$ & 0.856 \\
\hline 11 & & & Community Medicine & $34.52+6.08$ & 0.846 \\
\hline 12 & & & Eye & $34.92+6.09$ & 0.198 \\
\hline 13 & & & ENT & $34.34+6.22$ & 0.182 \\
\hline
\end{tabular}

Table-V. Department wise mean report on total faculty effectiveness score 


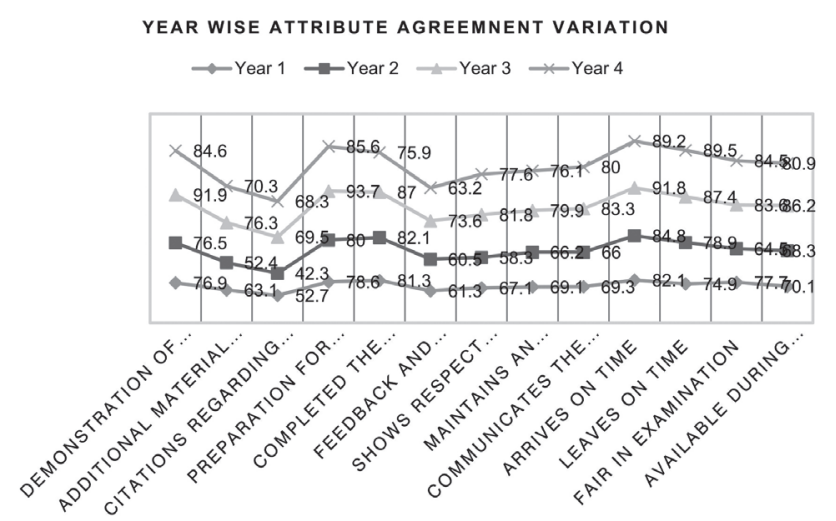

Figure-1. Year wise variation of agreement score attribute wise.

\section{DISCUSSION}

This study attempted to explore students' perception, characteristics that were deemed necessary for a medical teacher at undergraduate level. The instrument used for this purpose was approved by Higher Education Commission (HEC) of Pakistan. The prescribed format of Self-Assessment report by quality assurance department of HEC has this form. ${ }^{15}$

The attributes were divided in four broad categories; content, teaching methods, learning environment and teachers' personal attributes. The cumulative score from these categories was 39 marked as total faculty effectiveness score.

The agreement score percentage highlighted faculty's punctuality as the most perceived attribute followed by teachers' ability to complete the course on time. The score percentages improved in students from senior classes' i.e 3rd and 4th year MBBS. Attributes like faculty's demonstration of knowledge, his/her preparation for the class, his/her content for the lecture, communication skills and maintenance of an environment that is conducive to learning, student encouragement and his/her availability after class hours all improved with seniority of students. This may be due to more adjustment with the colleges' educational environment and more regulated learning as students become cognizant of their professional needs. Regular and constructive feedback is hall mark of medical education and was the key weakness identified

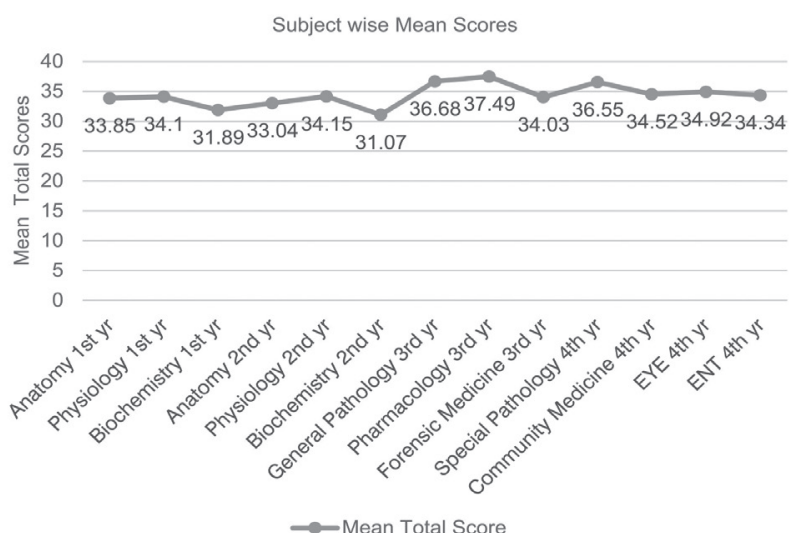

Figure-2. Department wise evaluation score graph

by the students across the board. The correlation analysis between total faculty ffectiveness score and surveyed attributes yield scores that were in close approximation however, the top three skills appreciated by students of Rehman Medical College (RMC) were faculty's demonstration of knowledge, their communication skills and their ability to maintain an environment that is conducive to learning.

The correlation analysis between total faculty effectiveness score and surveyed attributes yield scores that were in close approximation however, the top three skills appreciated by students of Rehman Medical College (RMC) were Faculty's demonstration of Knowledge, their communication skills and their ability to maintain an environment that conducive to learning.

In a study; what makes a good clinical teacher in medicine? By Sutkin et al broadly divided effective teaching in two categories; Cognitive and NonCognitive. Non - Cognitive includes emotional states, relationship skills, and personality types while cognitive skills include perception, memory, judgment, reasoning and procedural skills.13 Although Medical/clinical knowledge was the most cited descriptor but the overall analysis showed pre-dominance of non- cognitive skills which primarily were faculty's ability to communicate the subject matter and his/her overall communication skills and ability to maintain learning conducive environment. These results were consistent with our study where overall effectiveness score had 
significant and relatively strong correlation with communication skills and learning environment.

Similar findings were mentioned by McLean who surveyed second year medical students. In his study students preferred communication and personal skills compared with teaching, as in the present study. ${ }^{11}$

Teaching skills followed by inter-personal skills were ranked as important skills in a study by Kiani et $a l,{ }^{16}$ these results were somewhat similar to this study because in our study faculty's personal attributes were given more importance.

The disagreement between junior and senior years is consistent with the literature as the perception changes with each preceding year. ${ }^{2}$ However, which attributes are valued it depends purely on the faculty. In this study, $1^{\text {st }}$ and $4^{\text {th }}$ year MBBS differed with respect to content, teaching methods and learning environment.

The highly significant correlation between Faculty effectiveness score and $1^{\text {st }}$ and $2^{\text {nd }}$ year MBBS departments show that the teaching effectiveness cannot be judged by the variables on this form alone.

It is recommended that the survey form needs to be changed in the light of findings of this study and medical education literature. Students are stakeholders and their views helps teachers to become more self-aware. This self-awareness is the key for their improvement.

\section{CONCLUSION}

Medical and clinical knowledge is not sufficient alone in order to become a good teacher, it needs effective communication with students. Providing an environment that is conducive to learning and giving them respect are attributes that they can, not only observe but also feel. In the words of Reiser ${ }^{12}$ Teachers' duties to students should revolve around the attributes of candor, trust, and respect. Similarly, students' duties to teachers are those of reciprocity, honesty, and openness.

Copyright@ 15 May, 2019.

\section{REFERENCES}

1. Ilanlou M, Zand M. Professional competencies of teachers and the qualitative evaluation. Procedia Soc Behav Sci [Internet]. Elsevier B.V.; 2011;29:114350. Available from: http://dx.doi.org/10.1016/j. sbspro.2011.11.348

2. Jahan F, Sadaf S, Kalia S, Khan A, Hamza H Bin. Attributes of an effective clinical teacher: A survey on students' and teachers' perceptions. J Coll Physicians Surg Pakistan. 2008;18(6):357-61.

3. Prasertcharoensuk T, Somprach K, Ngang TK. Influence of Teacher Competency Factors and Students' Life Skills on Learning Achievement. Procedia - Soc Behav Sci [Internet]. Elsevier B.V.; 2015;186:566-72. Available from: http://linkinghub.elsevier.com/retrieve/ pii/S1877042815022818

4. Crosby RMHJ. AMEE Guide No 20: The good teacher is more than a lecturer - the twelve roles of the teacher. Med Teach [Internet]. 2000;22(4):334-47. Available from: http://www.tandfonline.com/doi/ full/10.1080/014215900409429

5. Abbasi MN, Malik A, Chaudhry IS, Imdadullah M. A study on student satisfaction in Pakistani universities: The case of Bahauddin Zakariya University, Pakistan. Asian Soc Sci. 2011;7(7):209-19.

6. Martirosyan NM, Saxon DP, Wanjohi R. Student satisfaction and academic performance in Armenian higher education. Am Int J Contemp Res. 2014;4(2):15 .

7. Bierer SB, Hull AL. Examination of a clinical teaching effectiveness instrument used for summative faculty assessment. Eval Heal Prof. 2007;30(4):339-61.

8. Pettit JE, Axelson RD, Ferguson KJ, Rosenbaum ME. Assessing effective teaching: What medical students value when developing evaluation instruments. Acad Med. 2015;90(1):94-9.

9. Ahmed R, Naqvi Z, Khurshid M. Results of faculty evaluation at the Aga Khan University, Karachi, Pakistan. J Pak Med Assoc. 1999;49(6):135-9.

10. Hwang JE, Kim NJ, Song M, Cui Y, Kim EJ, Park IA, et al. Individual class evaluation and effective teaching characteristics in integrated curricula. BMC Med Educ. BMC Medical Education; 2017;17(1):1-10.

11. McLean M. Qualities attributed to an ideal educator by medical students: Should faculty take cognizance? Med Teach. 2001;23(4):367-70. 
12. Hatem CJ, Searle NS, Gunderman R, Krane NK, Perkowski L, Schutze GE, et al. The educational attributes and responsibilities of effective medical educators. Acad Med. 2011;86(4):474-80.

13. Sutkin G, Wagner E, Harris I, Schiffer R. What makes a good clinical teacher in medicine? A review of the literature. Acad Med. 2008;83(5):452-66.

14. Singh S, Pai DR, Sinha NK, Kaur A, Soe HHK, Barua A. Qualities of an effective teacher: What do medical teachers think? BMC Med Educ [Internet]. BMC Medical Education; 2013;13(1):128. Available from: http://bmcmededuc.biomedcentral.com/ articles/10.1186/1472-6920-13-128
15. Batool, Zia; Qureshi RH. Quality assurance manual for Higher Education in Pakistan. High Educ Comm Pakistan [Internet]. 2007; Available from: http://www. iiu.edu.pk/wp-content/uploads/downloads/qec/HEC_ Quality_Assurance_Manual_for_Higher_Education_in_ Pakistan.pdf

16. Kiani $Q$, Umar $S$, Iqbal $M$. What do medical students expect in a teacher? Clin Teach. 2014;11(3):203-8.

\section{AUTHORSHIP AND CONTRIBUTION DECLARATION}

\begin{tabular}{|c|l|l|}
\hline Sr. \# & \multicolumn{1}{|c|}{ Author-s Full Name } & \multicolumn{1}{|c|}{ Contribution to the paper } \\
\hline 1 & Ali Raza & $\begin{array}{l}\text { Article research idea, manuscript } \\
\text { writing, data analysis. } \\
\text { Data collection, Data entry, } \\
\text { Literature review, Discussion. }\end{array}$ \\
\hline 2 & Hajira Zainab & \begin{tabular}{l} 
Hignature \\
\hline
\end{tabular} \\
\hline
\end{tabular}

